\title{
Adoption of Digital Marketing in E- Recruitment Success: A Quantitative Study on Bangladesh Perspective
}

\author{
Dr. Rumana Afroze (Corresponding author) \\ Assistant Professor, Department of Business Administration, \\ East West University, Bangladesh \\ A/2, Jahurul Islam Avenue, Dhaka, 1212, Bangladesh \\ Tel: 88-018-1888-3767_E-mail: rua@ewubd.edu
}

\begin{abstract}
Sujana Shafi
M.Sc. Research Student, Faculty of Business, Economics and Social Development, Universiti Malaysia Terengganu

21030 Kuala Nerus, Terengganu, Malaysia

Tel: 88-015-3357-8653; E-mail: sujanashafi006@gmail.com
\end{abstract}

Received: July 5, $2021 \quad$ Accepted: Oct. 8, $2021 \quad$ Published: Oct. 8, 2021

doi:10.5296/jmr.v13i4.18988～URL: https://doi.org/10.5296/jmr.v13i4.18988

\begin{abstract}
This study's purpose and strategies are to unwrap factors for the adoption of digital marketing strategies in the success of e-recruitment in Bangladesh. It also focuses on organizational perception, brand value, candidate and employer e- recruitment decisions in Bangladesh. In order to achieve the research objectives, a quantitative research has been done. A total of 138 human resource professionals from eleven prestigious job sectors in Bangladesh were contacted to participate in this study's survey. To conduct the research, a structured questionnaire was used. The collected data was analyzed using statistical analysis. Statistical tests like, descriptive analysis, reliability correlations, factor analysis and regression test were used to pursue the objective of analysis. The result has proved that adoption of digital marketing has significant impact on e- recruitment effectiveness. This study has practical implications for especially human resource departments and marketing managers and, such as
\end{abstract}




\section{Macrothink

the implementation of an integrated digital marketing and communication strategy with successful HR e-recruitment. This research incorporates digital marketing insights into well-established HRM fields.

Keywords: Digital marketing, E-recruitment, Brand awareness 


\section{Introduction}

With the rapid advancement of IT and the internet, the way HR functions are carried out is no longer the same as it once was. Human capital is one of the most valuable competitive advantages that companies can develop and maintain in today's business. E-recruitment is a new technological method for selecting one of a company's most important resources, human resources. (Karim et al., 2015).

The advent of internet technology has rewritten the rules of marketing all over the world. The internet has changed the way consumers interact with brands. It is changing the economics of marketing and rendering many of the function's traditional strategies and structures obsolete. The old way of doing business is no longer viable for marketers. (Kaur, 2017). Today, digital marketing has become one of the most important focus areas for businesses all over the world. It began as a means of communication and has evolved not only into another source of additional revenue but, more importantly, as a means of developing and maintaining long-term relationships with the various market participants. Interactivity, as the primary feature of the Internet, has enabled a new level of connectivity among all market participants. (Batinić, 2015).

Recruitment and selection, on the other hand, are critical for organizations because individuals with the necessary qualifications must be attracted on a timely basis. Recruitment and selection are critical in shaping an organization's effectiveness and performance, ensuring employee performance and positive organizational outcomes. In theory, using Information and Communication Technologies (ICT) for recruitment - a widely used Human Resource Management (HRM) tool - is standard practice in all types of organizations. E-recruitment is a branch of technology that has transformed the business world (Kumar \& Priyanka, 2014). Evidences showing a positive relationship between e-recruitment and organizational performance have been provided by researchers. The findings of research studies carried out by (Rahman et al., 2020) showed that e-recruitment had a positive relationship with the organizational performance.

The majority of the world's developed countries have implemented an e-recruitment policy. Even large corporations use digital technology to recruit from abroad. The largest digital job platforms are available to attract candidates from all over the world. Using the Internet, this technological innovation improves the process of recruiting knowledge sources. It enables businesses all over the world to save money, update job offers and status at any time, shorten the recruitment cycle time, identify and select the best knowledge potential from a larger pool of candidates, and gives the company an opportunity to improve its image and profile (Anand $\mathrm{J}, 2016$ ). In research from Mondy and Martocchio (2015) E-recruitment is defined as the process of identifying and attracting potential candidates, while selection is the process of making final decisions to select from those candidates via some selection tests. Many large corporations around the world have built their brands not only on their corporate websites, but also on the Social Media (SM) stage in order to reach an audience where those corporations can also share information about their businesses and available job opportunities with interested job seekers. E-recruitment is a tool that uses information technology to 
increase the efficiency, speed, and quality of the recruitment process from any location (Tong \& Sivanand, 2005).

The recruitment application records the details of recruitment and selection such as cost, process or method, and time to fill each job position, providing users with important information in real time. (Khashman \& Khashman, 2016). Selection, on the other hand, is the process of selecting qualified individuals to fill each position (Mathis et al., 2016). Any organization's recruitment and selection process should be carefully planned in order to identify the best fit candidates who best match the job requirements. As a result, whether an individual best matched the job to be filled was largely dependent on the appropriate pre-designed selection process. (Muqaddim \& Hosain, 2021).

Social networking sites (SNSs) such as LinkedIn, Facebook, Twitter, and Google+ can provide enrollment specialists with a wealth of information about potential candidates. Currently, the Web assists organizations in finding, attracting, and selecting candidates, as well as allowing managers to run an instant foundation check on candidates. Social media is a method of using information technology (IT), including the Internet, to perform, accelerate, or advance enlistment and decision-making methods and methodologies. (Melanthiou et al., 2015). Many businesses use such a platform to post outstanding job advertisements, making it easier for prospective employees to find jobs that are a good fit for them. In this regard, SNSs are making a difference by acting as a potential link between candidates and e-recruiters. Corporate Digital Media pages have recently proven to be an effective advertising medium with a few advantages over traditional job promotion media. Because the unemployment rate in many countries is high for a variety of reasons, the majority of business owners now have at least one SNS that highlights their company profiles. Employers are increasingly turning to social media for e-recruitment, realizing that they can reach a larger number of qualified job seekers this way. (Anand J, 2016).

In Bangladesh, number of internet subscribers is on the rise at a great speed 123.74 million as of July, 2021 (Internet | BTRC, 2021). Bangladesh is a newcomer to the e-recruitment adoption process, and as a result, there are many areas where employers must focus in order to fully capitalize on technological advancements. E-recruiting is one of the positive aspects of the internet. In the beginning, the e-recruitment system was mostly appreciated by the private sector in Bangladesh, but now, with the Bangladesh government's motto (Digital Bangladesh), the public sectors are also adopting the e-recruitment system. (Sultana, 2017). People in Bangladesh are increasingly adapting to technology, which is why e-recruitment has become a popular practice used by organizations to hire employees.

Multinational corporations, brands, and even small businesses have begun to use digital marketing for e-recruitment. The advancement of technology has a significant impact on the functioning of organizations and the overall development of Bangladesh. Because this country is still in its early stages and has set a goal of becoming fully digitalized in all areas, the organization has begun to incorporate technology into its operations. (Mindia \& Hoque, 2018). Recruitment via the internet is gaining traction slowly in Bangladesh, owing to the fact that the majority of people still believe in looking for work through the newspaper. Despite 
the fact that the number of internet users is large, people prefer to use the internet for specific purposes only. (Karim et al., 2015).

Thus analyzing the worldwide e-recruitment scenario, it is high time for a developing country like Bangladesh to go ahead with the utmost use of digital media and using e-recruitment. attempted to explore this area. The results of the study may assist the HR departments of the companies and can uplift them in designing and implementing e recruitment technologies within their organizations. This study will determine the effectiveness of e-recruitment and their scope in future.

\section{Objective of the study}

1. To identify information about using social medias for recruitment

2. To analyze the existing situation of companies whether they are using social media platforms

3. To develop a clear understanding about existing research related to social media and erecruitment

4. To understand what factors affect companies/ HR to utilize online digital media platforms for recruitment issues

\section{Problem Statement}

In the last decade, a small number of large organizations in Bangladesh have begun to implement the use of digital media for e-recruitment (Sabrina, 2014). The majority of businesses continue to underestimate the value of digital marketing and e-recruitment and have taken no or very few steps to create such an environment. Because it is still in its early stages, the introduction and implementation of digital marketing and e-recruitment in Bangladesh can be considered pioneering. However, in this day and age of fierce competition, businesses are constantly striving to reduce costs and gain a competitive advantage over their competitors (Rahman \& Hosain, 2021). In this regard, e-recruitment can be a successful tool for achieving such goals.

It is also environmentally friendly, which assists management in meeting a few social and environmental obligations. (Muqaddim \& Hosain, 2021).

The internet and digital marketing are serving a variety of purposes, including but not limited to e-recruitment, which is expanding its scope to a greater extent; however, it is still not universal to all. At the moment, the system has been adopted by only a few private sector firms, as well as a few public organizations, including Bangladesh's largest government job recruiter, the Public Service Commission (PSC). Despite the presence of some well-designed and informative portals in Bangladesh, businesses are still struggling to attract potential and desirable candidates to use such sites. The reasons may include a lack of proper job information, a lack of information about the firm and its policies, and difficulty or ignorance in using specific job sites. As a result, it is critical to create enticing content, as well as rich and user-friendly websites, in order to effectively attract applicants (Mishra \& Kumar 2019). 
Despite the rapid growth of internet usage, there is a gap between research and practice in digital marketing and e-recruitment (Muqaddim \& Hosain, 2021). In Bangladesh, digital marketing and social media platforms are thriving. With that in mind, most businesses all over the world are utilizing this media to improve their online presence as well as search for potential candidates. A background investigation revealed that there has been very little research done in Bangladesh on the adoption of digital platforms for e- recruitment.

Furthermore, it can be seen that, with the exception of a few well-known companies, the majority of companies use traditional forms of recruitment and are not particularly active in screening candidates from social media. They are even hesitant to openly post job postings on social media. In Bangladesh, the number of people using online platforms is increasing at an alarming rate, and the younger generation is clearly taking advantage of it.As a result, employers must identify the factors that must be implemented in order to make use of these online platforms worthy of looking for dynamic candidates for the appropriate position for the company.

\section{Research question}

1. Does digital marketing in e-recruitment minimize recruitment cost \& time?

2. Does digital marketing in e-recruitment generate e-candidate pipeline?

3. Does digital marketing in e-recruitment develop brand awareness of a company?

\section{Literature Review}

As a description of the processes involved in managing people in organizations, the terms 'human resource management' (HRM) and 'human resources' (HR) have largely replaced the term 'personnel management.' Human resource management is made up of three words: human, resource, and management. Human: refers to an organization's skilled workforce; resource: refers to limited availability or scarcity; and management: refers to maximizing or proper utilization and making the best use of limited and scarce resources (Rahman et al., 2020). HRM's primary function is Recruitment, one of the most important functions of HR, is becoming increasingly exposed to the internet, and many businesses are switching to electronic recruitment systems rather than traditional paper-based employee recruitment (Galhena \& Liyanage, 2014). Job seekers are also showing an interest in searching for job-related information and advertisements online rather than reading newspapers. It has been observed that potential candidates seek jobs through electronic sources in two ways: (1) through the company's own website, where the candidate finds job offers, and (2) through corporate job portals, where job advertisements are posted on behalf of the candidate's desired searching company.As a result, job portals act as agents for companies in their search for qualified candidates. Several job portals are now operational in Bangladesh, where job openings are regularly posted, and they are becoming increasingly popular among potential job seekers. (Hosain et al., 2016).

Anyone interested in the corporate world in the age of globalization is aware of job-sites. Prospective applicants could use the internet to search for positions in which they were 
interested. Direct contact with employers is a possibility. The ease of use of email surpassed the use of the telephone, fax, or mail, and businesses began accepting applications via email. Today organizations have their own websites, and job postings are available on job placement websites. Candidates can once again visit the websites, post their resumes, and contact the company directly. All of this is just a "click" away. E-recruitment is a tool used by many employers to find job candidates and by applicants to find jobs. (Muqaddim \& Hosain, 2021).

E-recruitment is only defined as the process of any personnel advertising or attracting, selection, and application processing via the Internet for external candidates or the Intranet for internal candidates (Mindia \& Hoque, 2018). The availability of internet connections, as well as high-speed and low-cost broadband connections Today's generation spends a lot of time on the internet. As a result, recruiters are focusing on making social media a tool for posting job opportunities on popular websites in order to attract a large pool of candidates from all over the world. (Rana \& Singh, 2015) discussed how employers can reach out to job seekers by creating profiles on Facebook and Linked In (social networking sites) as well as using job portals to make recruitment more effective. They can also advertise job openings with a variety of online recruitment agencies to kick start the talent search process.

Traditional enrollment strategies used by organizations include reaching out to friends or representative referrals in official attire, using daily newspaper classified advertisements, and others. When the company's approach, innovation, area, mergers, acquisitions, de-mergers, and employee renunciation change, this plan must be implemented on a regular basis to include, maintain, or re-adjust their workforce in accordance with corporate and human resource planning. (Yoon Kin Tong, 2009). Organizations now rely on digital media/online to recruit top talent as a result of globalization and technological advancement. Indeed, online recruitment is gaining traction over traditional enlistment methods in developing countries such as Bangladesh (Sultana \& Sultana, 2017). Digital marketing is a subset of social networking, which is defined as a network of interaction between people or businesses based on ties and connections. (Wasserman and Faust, 1994; Zoonen and Rice, 2017). In developed countries, research has been conducted to investigate the relationship between social media selection and commerce efficiency and competitive advantage (Jones et al., 2015), as well as how social media affects the formation and cultivation of social networks (Scott, 2017; (Ollington et al., 2013).

These studies emphasize the ability of digital and social media to help organizations develop, improve, succeed, and gain a competitive advantage (Boyd and Elliston, 2007). Many research studies (Ollington et al., 2013; Scott, 2017) highlight the positive aspects of social media and e-recruitment because many developed countries have strong legal protection for any strands of various qualities. This hypothesis contributes to the advancement and expansion of research into how businesses in developing countries can use social media for e-recruitment and selection. Most businesses must now work to establish a positive online image and dynamic nearness, as well as to maintain constant contact with their clients and other Web clients via social media destinations. In many businesses, the use of social media tools such as Facebook groups, company blogs, and Twitter accounts, among others, has 
become an important part of organizational procedures for growth and competitiveness, as well as for managing modern types of business risks..

To this end, McKinsey (2012) reported in 2012 that 70\% of organizations were regularly utilizing some form of social media for business viability. For example, the creation of Facebook in 2004, YouTube in 2005, and Twitter in 2006, as well as other social organizing stages (destinations), has resulted in an unprecedented wave of social engagement, promotion, and interaction among managers and employees, as well as stakeholder engagement. This insurgency can be seen not only in the digitization of social networking, but also in the organization of enrollment and choice data and information. (Shiraz, 2013; Christensen, 2011; Ghannam, 2011).

\section{Role of digital media in e-recruitment process}

Digital marketing and media have evolved into an enlistment tool in today's business world. Mishra and Kumar (2019) investigate this situation using the exploratory conceptual modeling approach, taking into account the positive impact of Web enrollment on the more youthful generation, as social media profiles of companies can have a positive impact on attracting potential applications. Several research studies, for example, highlight the role of social media in attracting potential applications among younger generations.

However, a number of studies have looked at this advancement from the perspective of employers. Melanthiou et al. (2015)'s research on 85 managers regarding digital and social media recruitment, on the other hand, shows that companies use digital media to screen candidates, and this approach provides earlier information on any applicants (Khlebarodava \& Remeikiene, 2019).

Traditional recruitment procedures are no longer effective in attracting the right and qualified candidates. As a result, many businesses have adopted modern recruitment methods, such as e-recruitment via digital media. E-recruitment is a web-based (online) or Web enlistment strategy distinguished by shifted components as well as a variety of hones, devices, and strategies for selecting candidates. (Tong \& Sivanand, 2005).

In summary, e-recruitment encompasses the following advanced HRM skills: career entrances, notice on work databases, corporate websites and intranets, social networking sites, and other online networks that encourage candidate screening, application submission oversight, tracking, and managing recruitment framework through search engines. According to Liu et al., (2018), social media platforms can be defined as a group of online applications that allow for the creation and exchange of user-generated content.

Davis's (1989) studies are also used to support research hypotheses in this study . Davis created the Technology Acceptance Model (TAM) to predict the impact of technology on individual behavior, which is now widely used and supported by extensive research (Galhena \& Liyanage, 2014). 
Dependent Variable

Adoption of Digital Marketing in E-recruitment

In this study digital marketing in e-recruitment depends on some of the factors. Those are given below:

\section{Independent Variable}

\section{Minimizing Recruitment Cost \& Time}

Advertisements on the internet are significantly less expensive than those in newspapers, magazines, and employment agencies. As in other sources, one must constantly revise; for example, if a company wanted their ad to appear on every Sunday for a month, they would have to pay for four advertisements. However, it does not apply to the internet. This reduces the amount of time it takes to deliver and communicate. Without any dellay, the response is direct and immediate. Prior to the postal services, fax was a one-way communication method that was time consuming. Phones allowed for two-way communication, but resume management and global communication were not possible. Because data collection, filing, and administrative tasks are completed electronically, paper work or documentation has been reduced (Mindia \& Hoque, 2018). Traditional enrollment methods are no longer adequate or convenient for attracting a large enough pool of qualified candidates. Many organizations have adopted modern recruitment methodologies or combined various recruitment strategies in order to attract them. (Tong and Sivanand, 2005).

Phones allowed for two-way communication but not resume management or global communication. Paper work or documentation has been reduced as data collection, filing, and administrative tasks are completed electronically (Mindia \& Hoque, 2018). Traditional methods of enrollment are no longer sufficient or convenient for attracting a large enough pool of qualified candidates. In order to attract them, many organizations have adopted modern recruitment methodologies or combined various recruitment strategies. Setting up a job advertisement on SM, for example, is frequently free, and the information can be changed if an error is discovered or a change is required (Sylva \& Mol 2009), whereas publishing a job advertisement in a newspaper requires a significant financial investment.

Cost efficiency and productivity are two of the research's findings. In comparison to traditional methods of recruitment and selection, such as the use of magazines and daily newspapers, as well as employment agencies, posting jobs and enlisting and selecting candidates on the Internet is essentially free (Shiraz, 2013). This method promotes efficiency as well as return on investment (ROI). The goal of e-recruitment is to make the forms included more competent, compelling, and cost-effective. You can reach a larger pool of potential candidates and encourage the selection process by recruiting online (Pollitt, 2005). Almost all interviewees agreed that e-recruitment is significantly more cost-effective and proficient than traditional methods because it reduces operational costs, printed materials/paper work, and authoritative costs. 
Because many companies' recruitment budgets have been stagnant for a long time, it is now more important than ever to maximize the recruitment marketing budget to achieve the best ROI. It also allows for significant savings in printed material, which lowers application costs. This method of finding candidates online replaces the traditional recruitment process of advertising, collecting resumes, and selecting the best candidates in a simple and cost-effective manner (Kumar \& Priyanka, 2014).

Thus Based on above discussion the proposed hypothesis in given below:

\section{H1: Digital marketing in e-recruitment minimizes recruitment cost \& time.}

Generating e-candidate pipeline

Attracting the "right" candidates is the most important aspect of digital marketing. Recruiters should concentrate on actively sourcing qualified individuals who are interested in new career opportunities as they become available, as well as on candidate engagement through significant discussions with targeted candidates to generate leads.

In the age of the internet, one's reach cannot be limited to a single location. It provides global reach in a fraction of a second. By creating a large pool of potential candidates, the process truly supports the definition of recruitment. Because detailed information is provided with clarity, a suitable candidate match is possible. The search is broadened by the possibility of linking to other websites, which attracts candidates, and after the job profile matches, the candidates apply. It serves as a repository of information, with information ranging from the job profile to the candidate profile, as well as past applicant data (Melanthiou et al., 2015). The goal of e-recruitment is to direct potential candidates to online job portals and encourage them to recommend the sites to their friends and family for future use. Kashi and Zheng's (2013) research provided insights in support. The study concluded that sometimes a job seeker only wants to post his/her CV to a specific jobsite and then retrieve the CV with a single click in order to resend it to the employer without resubmitting it.

The increased word limit for online job postings allows a company to communicate precise job data to prospective candidates, allowing them to self-screen and eliminate unsuitable candidates (Galanaki, 2002). One advantage of Social Networking Sites (SNS) is that they enable recruiters to reach out to "passive" candidates. Even if they are not actively looking for work, inactive candidates create and maintain professional profiles in the same way that active job seekers do because they believe it will bring them closer to the selection representative (Nikoloau, 2014). Targeted users can be effectively attracted by online promotion that is both intuitive and rich in mixed media content.

Furthermore, internet-based screening and testing support a company's recruitment efforts (Ngai et al., 2007). Using self-administered tests, organizations can use online pre-screening tools to automatically filter out the best applications from a large pool of applicants. An online recruitment system that is fully integrated can reduce administrative burdens and streamline the induction process (Barber, 2006). 
HR professionals frequently assert that business-oriented social networking sites (SNSs) contain a wealth of information about passive job seekers (Hossin \& Arefin, 2020). These people are especially appealing to businesses because they represent an underutilized pool of potential employees who are not connected with placement agencies or other recruiting professionals. Many passive candidates are thought to be especially stable employees, and he (DeKay, 2008) stated that the majority of LinkedIn members have a profile so that employers can contact them about new job opportunities. The majority of these profiles include detailed descriptions of current and previous work experiences, areas of expertise, and links to references provided by former bosses and coworkers.

The use of e-recruitment and social media platforms as a research recruitment strategy is a relatively new and topical recruitment method, as e-recruitment and social media platforms are also a relatively new technological development in the business environment (Herbell \& Zauszniewski, 2018) An effective strategy is a combination of various methods of E-recruitment, including effective job postings on job boards. Web portals enable, among other things, e-recruitment. In this way, successful corporations provide a more resourceful, flexible, and creative method of recruitment, making it more accessible to a larger number of potential employees (Wroblowska, 2016)

Thus Based on above discussion the proposed hypothesis in given below:

\section{H2: Digital marketing in e-recruitment generates e-candidate pipeline}

To develop online brand awareness of company

Brands are one of a company's most valuable assets, so brand management is an important activity in many industries. Employer branding is the application of branding principles to human resource management. Employer branding refers to a company's efforts to promote a clear picture of what makes it unique and appealing as an employer, both internally and externally (Backhaus \& Tikoo, 2004). The brand must be able to distinguish itself, create loyalty, fulfill potential candidates' needs, and establish an enthusiastic relationship with them (Davies, 2008).

As a result, a brand's esteem is proportional to its level of awareness/recognition and the image it conveys to individuals and new potential candidates. Any digital recruitment marketing strategy must prioritize the development of a distinct employer brand identity that complements the company's Core Value Proposition in the job market. Marketing must find a way to differentiate the company's EVP to their target group in today's job market. Creating an online presence takes time. Whether or not the company is currently hiring, their digital marketing strategy should include a plan for them to establish an online presence. (Reis \& Braga, 2016).

Many large corporations with a strong and active Web presence have built their brands not only on their corporate websites, but also on the SM platform, in order to reach a larger audience, allowing those corporations to share information about their businesses and available job opportunities with interested job seekers. Corporate social media pages have 
recently proven to be an effective advertising medium with several advantages over traditional job advertising media. (Hosain et al., 2020).

According to Woodko and Woniak (2017), one of the strengths of e-recruitment is broadening the scope of information used to improve corporation image and employer branding. Building employer branding, increasing people's awareness, and increasing the loyalty of current HR can increase the offer of job vacancies and obtain new well-educated and qualified human resources. According to (Gavurova et al., 2018), developing employer branding is also important in the online environment. Thus Based on above discussion the proposed hypothesis in given below:

\section{H3: Digital marketing in e-recruitment develops brand awareness of a company}

Based on the above discussion and the development of hypotheses, this study postulates the following research framework as shown in Figure

Conceptual framework of dependent \& independent variables

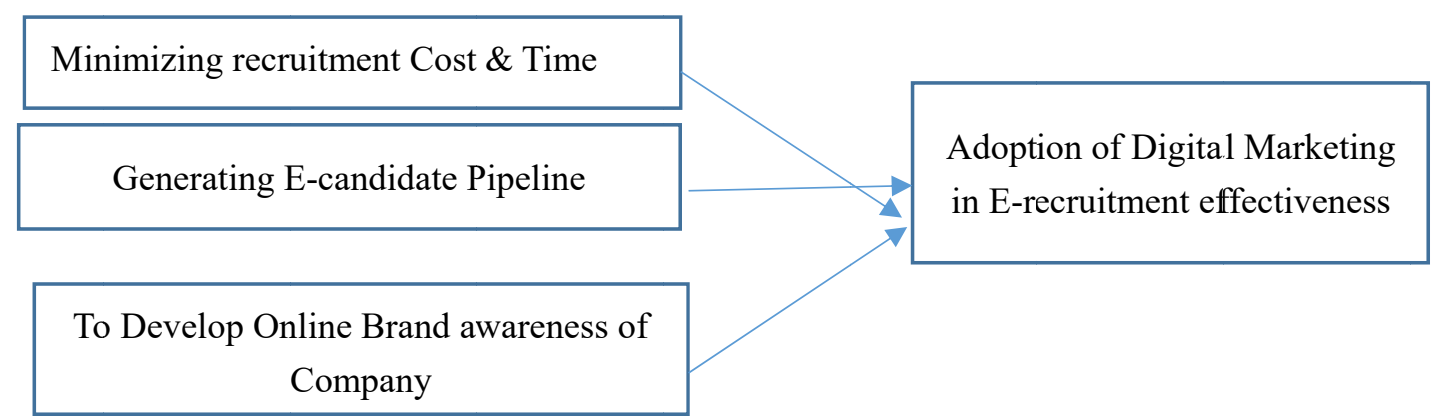

Figure 2.1. The conceptual framework for digital marketing in e-recruitment and variables

\section{Summary of Hypothesis Development}

Hypothesis is a specific statement of prediction. It describes terms what is expecting, here are four hypotheses have been selected. The hypotheses are:

H1: Digital marketing in e-recruitment minimizes recruitment cost \& time.

H2: Digital marketing in e-recruitment generates e-candidate pipeline

H3: Digital marketing in e-recruitment develops brand awareness of a company

\section{Methodology}

According to Cooper and Schindler (2014), in quantitative research method, survey is one of the most significant one. The study is based on collecting data from two variable groups, those are the primary data and secondary data. Primary data is the original data that has been collected by the researchers themselves specifically for the purpose in mind. Secondary data are data that have already been collected. These data can be located quickly and inexpensively. For this study data has been collected from different researches, news articles, social networking sites and other sources. 
Primary data has been collected from Bangladesh's top industry's human resource department. In particular, the sectors are RMG, Bank and financial, FMCG, Group of companies, logistic company, NGO, Airlines company, telecommunication, shipping companies, tobacco, IT/engineering companies \& others. Data have been collected through a detailed structured survey questionnaire from the respondents.

Here, sampling has done with types of 'qualified' respondents who may assist with the desired information what is needed for this study. The respondents of this study are active job holders in Human Resource Management department. For example, manager, deputy manager, assistant manager, senior executive etc. from various types of industries who has been contacted to attend the survey. A convenience sample is one that is drawn from a source that is conveniently accessible (Andrade, 2020). Convenience sampling (also known as availability sampling) is a specific type of non-probability sampling method that relies on data collection from population members who are conveniently available to participate in study (Saunders, 2019).

The respondents were selected using convenience sampling method from two big cities of Bangladesh: Dhaka (the capital) and Chittagong.

Survey research is defined as "the collection of information from a sample of individuals through their responses to questions". This type of research allows for a variety of methods to recruit participants, collect data, and utilize various methods of instrumentation. Survey research can use quantitative research strategies (e.g., using questionnaires with numerically rated items) (Check \& Schutt, 2011).

This study's questionnaire is consisting of respondent's demographic profile, and questions separately for dependent variable and independent variables. Demography (e.g., gender, mail, job level, and organization/industry type) and questions about digital marketing in e-recruitment, as well as independent variables related to minimizing recruitment cost and time, generating an e-candidate pipeline, and increasing brand awareness. The questionnaire was designed in such a way that respondents could easily move from one question to the next. For the questionnaire items, a 5-point Likert scale ranging from $1=$ strongly disagree to $5=$ strongly agree was used. The questionnaire was checked carefully to decide whether it was understandable and if there was any further improvement necessary. The questionnaire has been distributed online via google doc survey link after the targeted samples agreed to participate in this study. The online medium for instance, Email/ WhatsApp/ or through another network will be utilized and the google doc survey link has been shared to them. Statistical Package for the Social Sciences (SPSS) version 26 has been used to perform all the statistics analysis.

Researchers have proposed the bare minimum of subjects required for various types of research. For descriptive studies, a sample size of at least 100 is needed (Fraenkel et al., 2011). A total of 138 responses got among them male 83 and female 55. After collecting the data, internal consistency was checked by using the Cronbach alpha $(\alpha)$ test. Results are discussed in sections like "Demography," "Reliability," "Exploratory Factor Analysis," and "Multiple Regression Analysis" pertain to dependent variable adoption of digital marketing 
in e-recruitment \& independent variables are minimizing recruitment cost and time, generating e-candidate pipeline and brand awareness. Data analysis was carried out using the SPSS version 26.

\section{Mathematical Framework}

The equation is

$$
\mathrm{Y}=\mathrm{a}+\mathrm{b} 1 \mathrm{X} 1+\mathrm{b} 2 \mathrm{X} 2+\mathrm{b} 3 \mathrm{X} 3
$$

Where:

$\mathrm{Y}=$ the value of the Dependent variable (Adoption of digital marketing in e-recruitment), what is being predicted.

$\mathrm{a}=($ Alpha) the Constant or intercept, $\mathrm{b} 1=$ The Slope (Beta coefficient) for X1, b2 = The Slope (Beta coefficient) for X2, b3 = The Slope (Beta coefficient) for X3.

$\mathrm{X} 1=$ First independent variable (Minimizing Recruitment Cost \& Time) that is explaining the variance in $\mathrm{Y}$ (Adoption of digital marketing in e-recruitment)

$\mathrm{X} 2$ = Second independent variable (Generating e-candidate pipeline) that is explaining the variance in Y (Adoption of digital marketing in e-recruitment)

$\mathrm{X} 3$ = Third independent variable (To develop online brand awareness of company) that is explaining the variance in Y (Adoption of digital marketing in e-recruitment)

The regression model describes how dependent variables are related to independent variables.

\section{Analysis and Result}

\section{Respondent's Demography}

Personal characteristics that are used to collect and evaluate data from the general population are referred to as demographic factors. Prior to conducting the research, some demographic factors from a Bangladeshi perspective, including gender, mail, job level, and industry have identified. The following frequency table analyzes all demographic data. Table 4.1 shows the gender information of respondents.

Table 4.1. Gender information of the respondents

\begin{tabular}{llllll}
\hline & & & & Valid & $\begin{array}{l}\text { Cumulative } \\
\text { Percent }\end{array}$ \\
\hline Valid & Male & 83 & 58.0 & 60.1 & 60.1 \\
& Female & 55 & 38.5 & 39.9 & 100.0 \\
& Total & 138 & 96.5 & 100.0 & \\
Missing & System & 5 & 3.5 & & \\
Total & & 143 & 100.0 & & \\
\hline
\end{tabular}




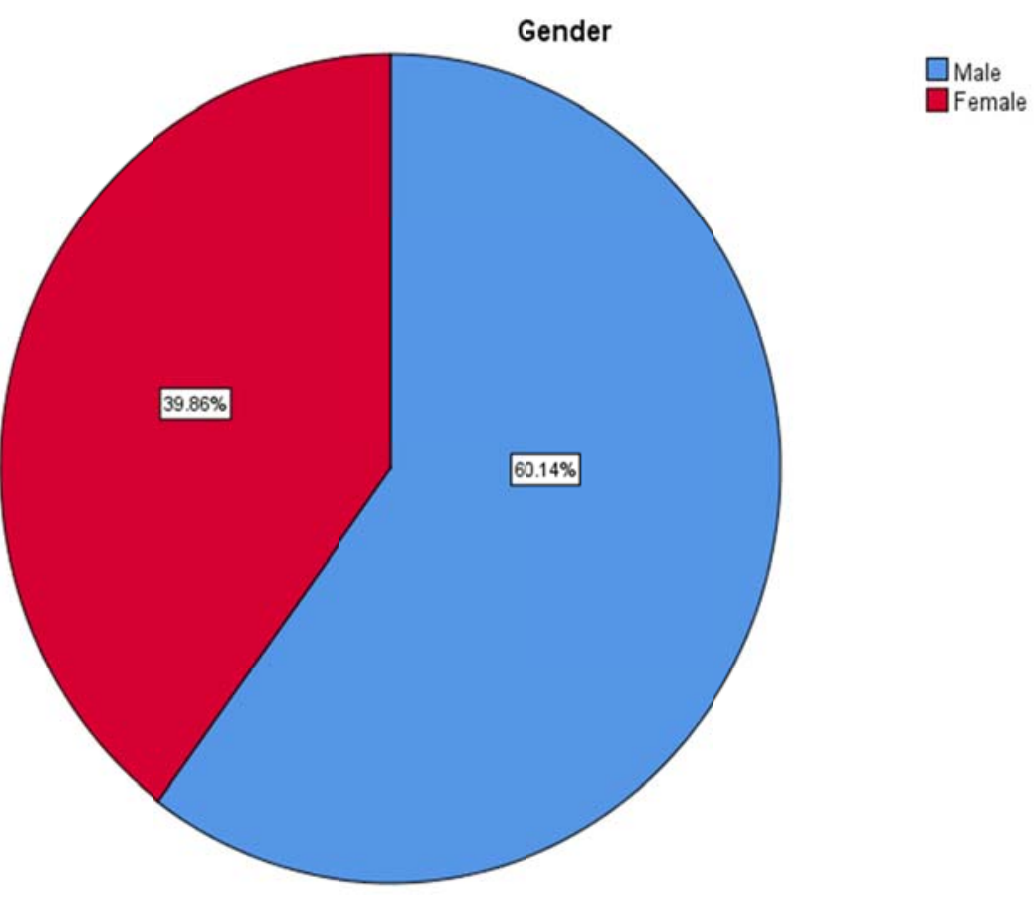

Figure 4.1. Respondent's demography pie chart (Gender)

In this survey, 138 participants have been taken. And within these participants, 55 females and 83 males. The above pie chart shows that in the survey of $100 \%$ respondent where $60.14 \%$ was male and $39.86 \%$ was female.

Table 4.2 represents the exact number of respondent along with their level of job with percentage.

Table 4.2. Designation information of the respondents.

\begin{tabular}{llllll}
\hline & & & & $\begin{array}{l}\text { Valid } \\
\text { Percent }\end{array}$ & $\begin{array}{l}\text { Cumulative } \\
\text { Percent }\end{array}$ \\
\hline Valid & Entry Level & 50 & 35.0 & 36.2 & 36.2 \\
& Mid Level & 22 & 15.4 & 15.9 & 52.2 \\
& Senior & 66 & 46.2 & 47.8 & 100.0 \\
& Level & & & & \\
& Total & 138 & 96.5 & 100.0 & \\
Missing & System & 5 & 3.5 & & \\
Total & & 143 & 100.0 & & \\
\hline
\end{tabular}




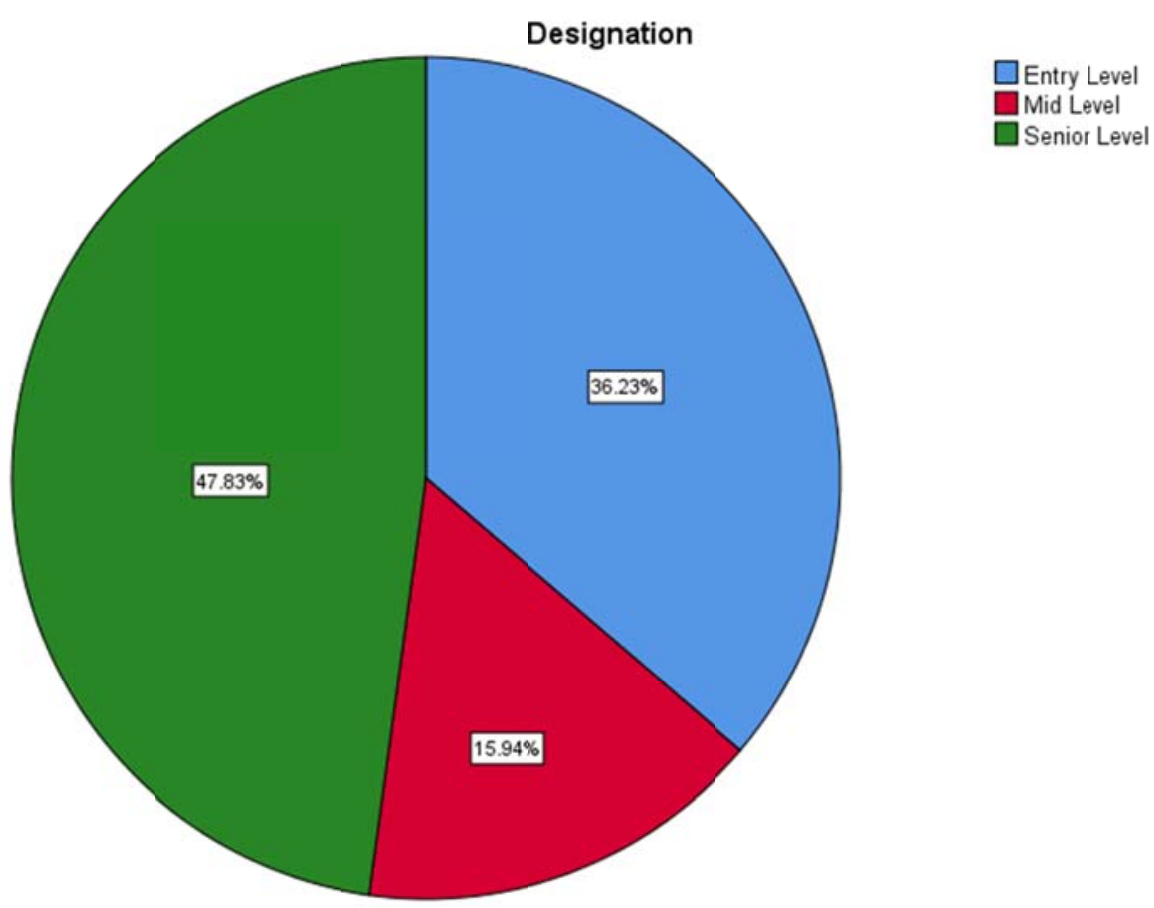

Figure 4.2. Par chart of respondent's demography (Job Designation/ Level)

In figure 4.2 it can be seen the designation of respondents. The designation has been categorized in to 3 levels. Those are, entry level, mid-level \& senior level. From the pie chart it can be seen that valid responses out of $100 \%$ from senior level $47.83 \%$, from mid-level $15.94 \%$ and from entry level $36.23 \%$.

Table 4.3 represents the industries where the respondents work and number of responses from each industry with percentage. 
Table 4.3. Organization information of the respondents

Organization

\begin{tabular}{|c|c|c|c|c|c|}
\hline & & Frequency & Percent & $\begin{array}{l}\text { Valid } \\
\text { Percent }\end{array}$ & $\begin{array}{l}\text { Cumulative } \\
\text { Percent }\end{array}$ \\
\hline \multirow[t]{16}{*}{ Valid } & Bank \& & 13 & 9.1 & 9.4 & 9.4 \\
\hline & Company & & & & \\
\hline & RMG & 23 & 16.1 & 16.7 & 26.1 \\
\hline & FMCG & 15 & 10.5 & 10.9 & 37.0 \\
\hline & Group of Companies & 13 & 9.1 & 9.4 & 46.4 \\
\hline & Logistic company & 11 & 7.7 & 8.0 & 54.3 \\
\hline & Telecommunication & 5 & 3.5 & 3.6 & 58.0 \\
\hline & Company & & & & \\
\hline & $\mathrm{NGO}$ & 14 & 9.8 & 10.1 & 68.1 \\
\hline & Airlines Company & 4 & 2.8 & 2.9 & 71.0 \\
\hline & Shipping Company & 5 & 3.5 & 3.6 & 74.6 \\
\hline & Tobacco Company & 3 & 2.1 & 2.2 & 76.8 \\
\hline & IT/ Engineering & 9 & 6.3 & 6.5 & 83.3 \\
\hline & Company & & & & \\
\hline & Others & 23 & 16.1 & 16.7 & 100.0 \\
\hline & Total & 138 & 96.5 & 100.0 & \\
\hline Missing & System & 5 & 3.5 & & \\
\hline Total & & 143 & 100.0 & & \\
\hline
\end{tabular}




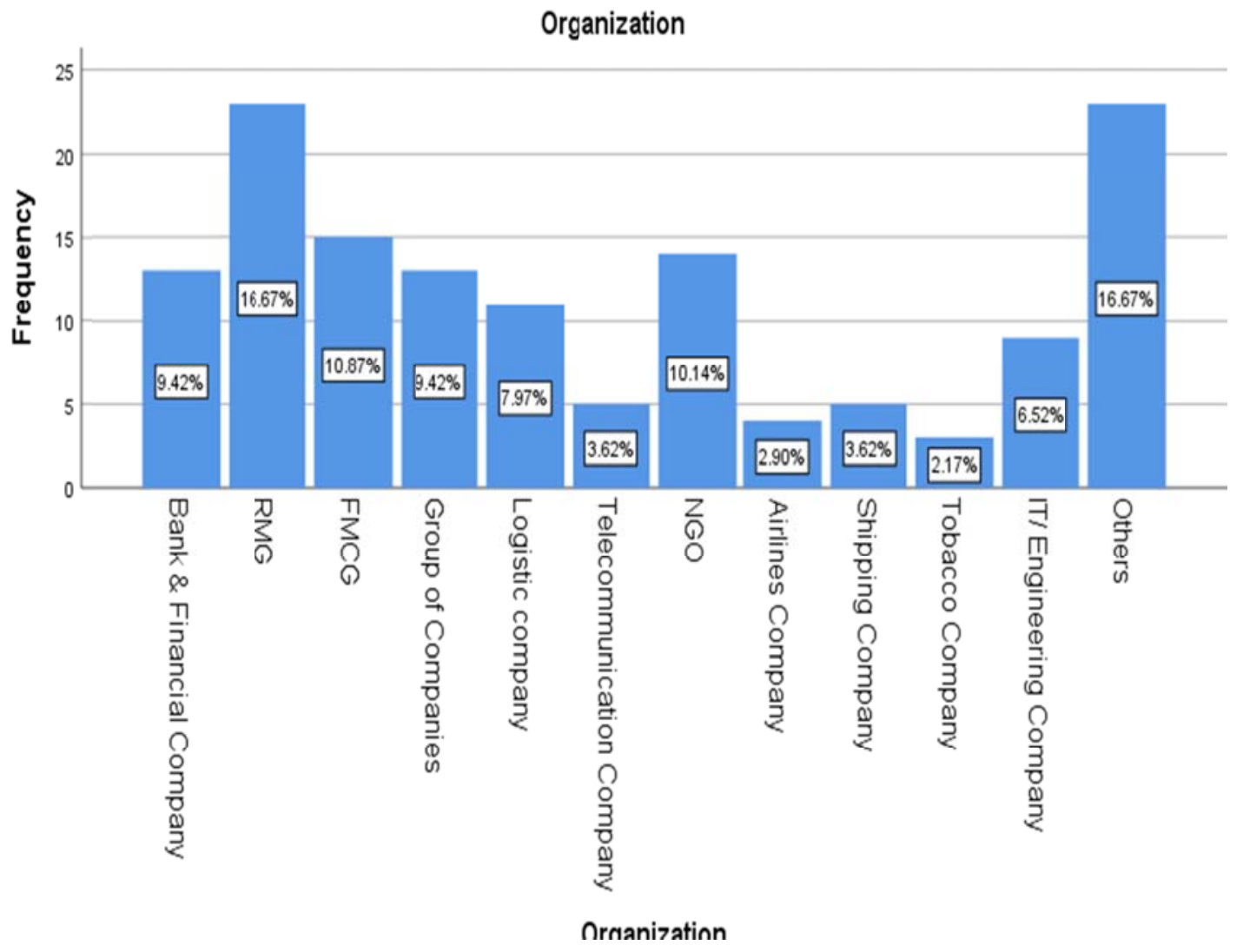

Figure 4.3. Bar chart of respondent's demography (Organization)

Figure 4 shows the bar chart of organization/ industry of respondents. There are lots of companies in Bangladesh. So divided the top most significant 11 sectors Bank \& Financial Company, RMG, FMCG, Group of Companies, Logistic company, Telecommunication Company, NGO, Airlines Company, Shipping Company, Tobacco Company, IT/ Engineering Company \& others. The percentage wise response out of $100 \%$ are as given in the following Bar Chart.

\section{Reliability Statistics}

The properties of measurement scales and the items that comprise the scales can be studied using reliability analysis. The Reliability Analysis procedure computes a number of commonly used measures of scale reliability as well as information about the relationships between individual scale items.

\section{Cronbach's Alpha}

A larger number of items can lead to a larger, and a smaller number of items can lead to a smaller. If alpha is high, this could indicate that they're asking the same questions (i.e., they're asking the same thing. A low alpha value may indicate that there aren't enough questions on the test. 
Dependent Variable

Adoption of Digital Marketing

Table 4.4 illustrates Cronbach alpha value for dependent variable.

Table 4.4. Cronbach alpha $(\alpha)$ value

Reliability Statistics

Cronbach's Alpha Cronbach's Alpha Based on Standardized Items N of Items

$\begin{array}{lll}.828 & .830 & 2\end{array}$

Table 4.5. delineates valid and excluded case processing summary.

Table 4.5. Case Processing Summary

\begin{tabular}{llll}
\hline & & $\mathrm{N}$ & $\%$ \\
\hline Cases & Valid & 138 & 96.5 \\
& Excluded $^{\mathrm{a}}$ & 5 & 3.5 \\
& Total & 143 & 100.0 \\
\cline { 2 - 4 }
\end{tabular}

a. Listwise deletion based on all variables in the procedure.

The value of Benchmark of Cronbach's alpha is greater than 0.7 that mean data are reliable. In this study, the value of Benchmark of Cronbach's alpha is 0.828 that mean data of Adoption of Digital Marketing are reliable and acceptable.

Independent Variable

1: Minimizing Recruitment Cost \& Time:

Table 4.6 illustrates Cronbach alpha value for independent variable

Table 4.6. Cronbach alpha $(\alpha)$ value

Reliability Statistics

\begin{tabular}{lll}
\hline Cronbach's Alpha & Cronbach's Alpha Based on Standardized Items & N of Items \\
\hline .904 & .904 & 3 \\
\hline
\end{tabular}


Table 4.7. delineates valid and excluded case processing summary.

Table 4.7. Case Processing Summary

\begin{tabular}{llll}
\hline & & $\mathrm{N}$ & $\%$ \\
\hline Cases & Valid & 138 & 96.5 \\
& Excluded $^{\mathrm{a}}$ & 5 & 3.5 \\
& Total & 143 & 100.0 \\
\hline
\end{tabular}

a. Listwise deletion based on all variables in the procedure.

The value of Benchmark of Cronbach's alpha is greater than 0.7 that mean data are reliable. In this study, the value of Benchmark of Cronbach's alpha is 0.904 that mean data of Minimizing Recruitment Cost \& Time are reliable and acceptable.

2: Generating E-candidate Pipeline

Table 4.8 illustrates Cronbach alpha value for independent variable.

Table 4.8. Cronbach alpha $(\alpha)$ value

\begin{tabular}{lll}
\multicolumn{2}{l}{ Reliability Statistics } \\
\begin{tabular}{lll} 
Cronbach's Alpha Cronbach's Alpha Based on Standardized Items & N of Items \\
\hline .872 & .875 & 3 \\
\hline
\end{tabular}
\end{tabular}

Table 4.9. delineates valid and excluded case processing summary

Table 4.9. Case Processing Summary

\begin{tabular}{llll}
\hline & & $\mathrm{N}$ & $\%$ \\
\hline Cases & Valid & 138 & 96.5 \\
& Excluded $^{\mathrm{a}}$ & 5 & 3.5 \\
& Total & 143 & 100.0 \\
\hline
\end{tabular}

a. List wise deletion based on all variables in the procedure.

The value of Benchmark of Cronbach's alpha is greater than 0.7 that mean data are reliable. In this study, the value of Benchmark of Cronbach's alpha is 0.872 that mean data of Generating E-candidate Pipeline are reliable and acceptable.

3: To Develop Online Brand awareness of Company

Table 4.10 illustrates Cronbach alpha value for independent variable. 
Table 4.10. Cronbach alpha $(\alpha)$ value

Reliability Statistics

\begin{tabular}{|c|c|c|}
\hline $\begin{array}{l}\text { Cronbach's } \\
\text { Alpha }\end{array}$ & $\begin{array}{l}\text { Cronbach's } \\
\text { Alpha Based } \\
\text { on } \\
\text { Standardized } \\
\text { Items }\end{array}$ & $\mathrm{N}$ of Items \\
\hline .928 & .929 & 3 \\
\hline
\end{tabular}

Table 4.11. delineates valid and excluded case processing summary.

Table 4.11. Case Processing Summary

\begin{tabular}{llll}
\hline & & $\mathrm{N}$ & $\%$ \\
\hline Cases & Valid & 138 & 96.5 \\
& Excluded $^{\mathrm{a}}$ & 5 & 3.5 \\
& Total & 143 & 100.0 \\
\hline
\end{tabular}

a. Listwise deletion based on all variables in the procedure.

The value of Benchmark of Cronbach's alpha is greater than 0.7 that mean data are reliable. In this study, the value of Benchmark of Cronbach's alpha is 0.928 that mean data of "To Develop Online Brand awareness of Company" are reliable and acceptable.

\section{Factor Analysis}

Table 4.12 represents $\mathrm{KMO}$ test. It is important to test the adequacy of the sample respondents. The adequacy of the number of respondents can be tested by KMO \& Bartlett's test. KMO \& Bartlett's test shows the acceptability of the sample respondents. The tests identify whether the total number of respondents is good enough for the study or not. In order to find the sufficiency level of the number of respondents, each test has a benchmark value which should be followed by comparing it with the actual value.

KMO Bartletts 
Table 4.12. KMO and Bartlett's Test

\begin{tabular}{lcl}
\hline $\begin{array}{l}\text { Kaiser-Meyer-Olkin } \\
\text { Adequacy. }\end{array}$ & Measure of Sampling & .850 \\
Bartlett's Test & of Approx. Chi-Square & 1190.901 \\
Sphericity & df & 55 \\
& Sig. & .000 \\
\hline
\end{tabular}

KMO is a measure of sampling adequacy by Kaiser, Meyer \& Olkin. It has a benchmark value of .70. If the KMO value of the sample respondents is less than .70 then the number of respondents is not good enough for the study. On the other hand, if the value is more than .70 then the number of respondents is good enough for the study.

Bartlett's test shows the significance level of the respondents which is another measure of sampling adequacy. In Bartlett's test the benchmark value is .05 where if the significance value is less than .05 then null hypotheses will be rejected and if the significance value is greater than .05 then null hypotheses will be accepted.

Here the hypothesis is: -

H0: Total number of respondents is not significantly adequate for the study.

H1: Total number of respondents is significantly adequate for the study.

According to the KMO measure of sampling adequacy, number of respondents for this study is good enough because the value is 0.850 which is greater than the benchmark value .70 .

According to the Bartlett's test, the value of significance level is .000 which is less than the benchmark value .05 . As a result, the null hypotheses is rejected and alternative hypotheses is accepted.

After conducting the tests mentioned above, it can be concluded that respondents group is good enough to continue research.

The value of Benchmark of Cronbach's alpha is greater than 0.7 that mean data are reliable. In this study, the value of Benchmark of Cronbach's alpha is 0.828 that mean data of Adoption of Digital Marketing are reliable and acceptable.

\section{Communalities}

Table 4.13 represents communalities extraction values. Through the communalities table it can find out the questions which are appropriate for this study and which are not relevant with this study. 
Table 4.13. Communalities

\begin{tabular}{|c|c|c|}
\hline & Initial & $\begin{array}{l}\text { Extractio } \\
\mathrm{n}\end{array}$ \\
\hline $\mathrm{DV}_{-} 1$ & 1.000 & .681 \\
\hline DV_2 & 1.000 & .674 \\
\hline Cost_1 & 1.000 & .811 \\
\hline Cost_2 & 1.000 & .736 \\
\hline Cost_3 & 1.000 & .804 \\
\hline Candidate_1 & 1.000 & .789 \\
\hline Candidate_2 & 1.000 & .746 \\
\hline Candidate_3 & 1.000 & .884 \\
\hline Brand_1 & 1.000 & .913 \\
\hline Brand_2 & 1.000 & .824 \\
\hline Brand_3 & 1.000 & .864 \\
\hline
\end{tabular}

Here, by the extraction values it can measure the relevancy of the questions with the study where the highest range for extraction value is 1 . The closer the value to 1 represents better relevancy of the question to the study. The lowest benchmark value is 0.5 . If the extraction value is less than 0.5 then the item is not good enough for the study.

Here from the communalities table it can be seen that there's no value less than 0.5. Most of them are quite close to the value 1 . So it can be concluded that questions are appropriate for the study.

Total Variance explained

Table 4.14 presents The Total Variance Explained table that categorizes data and explains the integrity of the questions on the questionnaire. 
Table 4.14. Total Variance Explained

\begin{tabular}{lllllll}
\hline & \multicolumn{3}{c}{ Initial Eigenvalues } & \multicolumn{3}{c}{ Extraction Sums of Squared Loadings } \\
Component & Total & Variance & of Cumulative & & $\%$ & of Cumulative \\
\% & \% & Total & Variance & $\%$ \\
\hline 1 & 6.199 & 56.358 & 56.358 & 6.199 & 56.358 & 56.358 \\
2 & 1.465 & 13.315 & 69.673 & 1.465 & 13.315 & 69.673 \\
3 & 1.063 & 9.661 & 79.335 & 1.063 & 9.661 & 79.335 \\
4 & .633 & 5.754 & 85.088 & & & \\
5 & .407 & 3.696 & 88.784 & & & \\
6 & .324 & 2.943 & 91.726 & & & \\
7 & .246 & 2.232 & 93.958 & & & \\
8 & .225 & 2.048 & 96.006 & & & \\
9 & .180 & 1.641 & 97.647 & & & \\
10 & .164 & 1.488 & 99.135 & & & \\
11 & .095 & .865 & 100.000 & & & \\
\hline
\end{tabular}

Extraction Method: Principal Component Analysis.

If the cumulative percentage is $60 \%$ or above, it means that the independent variables have explained the dependent variable. From here, that 79.335 variation of the dependent. Which is higher than the benchmark. So independent variables surely explained properly the dependent variables in this study.

Component Matrix

Table 4.15 illustrates component matrix with principal component analysis of dependent and independent variables. 
Table 4.15. Component Matrix ${ }^{\mathrm{a}}$

\begin{tabular}{llll}
\hline \multicolumn{5}{l}{ Component } \\
& 1 & 2 & 3 \\
\hline DV_1 & .713 & & \\
DV_2 & .748 & & \\
Cost_1 & .797 & & \\
Cost_2 & .790 & & \\
Cost_3 & .757 & & \\
Candidate_1 & .604 & .630 & \\
Candidate_2 & .736 & .421 & \\
Candidate_3 & .671 & .618 & \\
Brand_1 & .805 & & -.515 \\
Brand_2 & .811 & & \\
Brand_3 & .800 & & -.474 \\
\hline
\end{tabular}

Extraction Method: Principal Component

Analysis. 3 components extracted.

Component Score Coefficient Matrix

\begin{tabular}{llll}
\hline \multicolumn{4}{c}{ Component } \\
& 1 & 2 & 3 \\
\hline DV_1 & .115 & -.277 & -.091 \\
DV_2 & .121 & -.177 & .203 \\
Cost_1 & .128 & -.231 & .233 \\
Cost_2 & .127 & -.170 & .212 \\
Cost_3 & .122 & -.211 & .347 \\
Candidate_1 & .097 & .430 & .154 \\
Candidate_2 & .119 & .287 & .157 \\
Candidate_3 & .108 & .422 & .213 \\
Brand_1 & .130 & .012 & -.484 \\
Brand_2 & .131 & .041 & -.380 \\
Brand_3 & .129 & .013 & -.446 \\
\hline Extraction & Method: & Principal & Component \\
Analysis. & & &
\end{tabular}

Correlations

Table 4.16 represents Correlation Matrix of dependent and independent wariables which are determined by the squared multiple correlation of the variable itself and with the other variables. With the Correlation Matrix want to show the interrelationship among all the components. 
Table 4.16. Table correlation

\begin{tabular}{|c|c|c|c|c|c|}
\hline & \multicolumn{4}{|c|}{$\begin{array}{l}\mathrm{DM} \text { in } \\
\text { e-recruitme }\end{array}$} \\
\hline & & $\mathrm{nt}$ & Cost & Candidate & Brand \\
\hline \multirow{4}{*}{$\begin{array}{l}\mathrm{DM} \text { in } \\
\text { e-recruitm } \\
\text { ent }\end{array}$} & Pearson & 1 & $.681^{* *}$ & $.403^{* *}$ & $.591^{* *}$ \\
\hline & Correlation & & & & \\
\hline & Sig. (2-tailed) & & .000 & .000 & .000 \\
\hline & $\mathrm{N}$ & 138 & 138 & 138 & 138 \\
\hline \multirow[t]{4}{*}{ Cost } & Pearson & $.681^{* *}$ & 1 & $.477^{* *}$ & $.594^{* *}$ \\
\hline & Correlation & & & & \\
\hline & Sig. (2-tailed) & .000 & & .000 & .000 \\
\hline & $\mathrm{N}$ & 138 & 138 & 138 & 138 \\
\hline \multirow[t]{4}{*}{ Candidate } & Pearson & $.403^{* *}$ & $.477^{* *}$ & 1 & $.550^{* *}$ \\
\hline & Correlation & & & & \\
\hline & Sig. (2-tailed) & .000 & .000 & & .000 \\
\hline & $\mathrm{N}$ & 138 & 138 & 138 & 138 \\
\hline \multirow[t]{4}{*}{ Brand } & Pearson & $.591^{* *}$ & $.594^{* *}$ & $.550^{* *}$ & 1 \\
\hline & Correlation & & & & \\
\hline & Sig. (2-tailed) & .000 & .000 & .000 & \\
\hline & $\mathrm{N}$ & 138 & 138 & 138 & 138 \\
\hline
\end{tabular}

**. Correlation is significant at the 0.01 level (2-tailed).

Here, can see that all the *marked values are more than 0.3 . So, that there is no weak relationship between the dependent and independent variables. All are moderate and strong relationship the table depicts.

Regression

Regression analysis is a set of statistical methods used to estimate relationships between a dependent variable and one or more independent variables. 


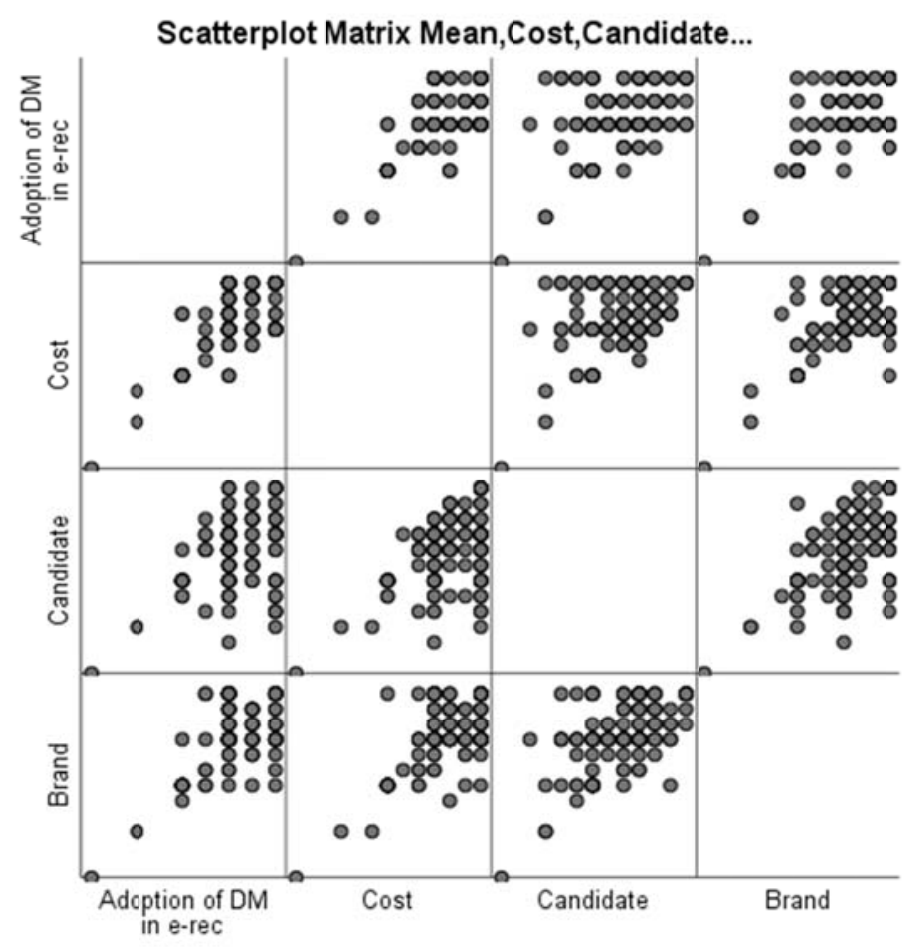

Figure 4.4. Scatterplot Matrix Linear Relationship

From the above figure 4.4 scatterplot there is a complete linear line in three of the cases with dependent and independent variable relationships.

Table 4.17. Variables Entered/Removed ${ }^{\mathrm{a}}$

\begin{tabular}{llll}
\hline Model & Variables Entered & Variables Removed & Method \\
\hline 1 & Brand, Candidate, Cost $^{\mathrm{b}}$ & . & Enter
\end{tabular}

a. Dependent Variable: Adoption of Digital Marketing in E-recruitment effectiveness

b. All requested variables entered.

From the table 4.17 above shows that four independent variables remain exist that were developed before conducting the survey. There is no variable to remove. It indicates that the four of independent variables- Brand awareness, e-candidate pipeline \& minimizing recruitment cost and time are influencing Adoption of Digital Marketing in E-recruitment effectiveness in Bangladesh. 
Table 4.18. Model Summary

\begin{tabular}{lllll}
\hline Model & R & R Square & $\begin{array}{l}\text { Adjusted } \\
\text { Square }\end{array}$ & $\begin{array}{c}\text { R Std. Error of } \\
\text { the Estimate }\end{array}$ \\
\hline 1 & $.719^{\mathrm{a}}$ & .517 & .507 & .47975 \\
\hline
\end{tabular}

a. Predictors: (Constant), Brand, Candidate, Cost

Model Summary from above table 4.18 table gives information about regression line's capacity to represent the total variation in the dependent variable. It means whether the independent variables are able to judge the dependent variable or not. Model summary is comprised with R, R Square, adjusted R Square and Std. Error of the Estimation.

Table 4.19 shows Anova of regression for whether the hypothesis will be rejected or accepted.

Table 4.19. ANOVA ${ }^{\mathrm{a}}$

\begin{tabular}{|c|c|c|c|c|c|c|}
\hline Model & & $\begin{array}{l}\text { Sum } \\
\text { Squares }\end{array}$ & $\mathrm{df}$ & Mean Square & $\mathrm{F}$ & Sig. \\
\hline \multirow[t]{3}{*}{1} & Regression & 33.065 & 3 & 11.022 & 47.888 & $.000^{\mathrm{b}}$ \\
\hline & Residual & 30.841 & 134 & .230 & & \\
\hline & Total & 63.906 & 137 & & & \\
\hline
\end{tabular}

a. Dependent Variable: DM in e-recruitment

b. Predictors: (Constant), Brand, Candidate, Cost

The decision regarding the hypothesis is dependent on the P-value (level of significance) by comparing the alpha value (.05). ANOVA usually is the justification of P-value and the justification will be on the basis of the following criteria:

If $\mathrm{P}$ value $<\alpha, \mathrm{H} 0$ is rejected.

If $\mathrm{P}$ value $>\alpha, \mathrm{H} 0$ is accepted.

From the ANOVA table, it can be seen that the level of significance is .000 which is less than .05 . So, the null hypothesis can be rejected and that means null hypothesis is rejected. So, given independent variable is good enough to explain the dependent variable.

From the below table 4.20, it shows coefficient indicates the specific relationship among the independent variables and dependent variables. It accurately refers to the extent to which the specific factor which can affect the dependable variables. 
Table 4.20. Coefficients ${ }^{\mathrm{a}}$

\begin{tabular}{lllllll}
\hline \multicolumn{1}{l}{} & \multicolumn{2}{l}{$\begin{array}{l}\text { Unstandardized } \\
\text { Coefficients }\end{array}$} & $\begin{array}{l}\text { Standardized } \\
\text { Coefficients }\end{array}$ & \\
Model & & $\mathrm{B}$ & Std. Error & Beta & $\mathrm{t}$ & Sig. \\
\hline 1 & (Constant) & .906 & .277 & & 3.268 & .001 \\
& Cost & .493 & .074 & .509 & 6.646 & .000 \\
& Candidate & .001 & .066 & .001 & .017 & .987 \\
& Brand & .279 & .078 & .289 & 3.586 & .000 \\
\hline
\end{tabular}

a. Dependent Variable: Adoption of Digital Marketing in e-recruitment effectiveness

The discussion of hypothesis from the table 4.20 is given below.

Hypothesis 1

Here Cost significant value is (0.000). As the significant value is less than .05 So, here Null Hypothesis got rejected and alternative hypothesis got accepted.

So, it proves Digital marketing in e-recruitment minimizes recruitment cost \& time

Hypothesis 2

Here candidate significant value is $(0.987)$. As significant value is more than .05 So, here alternative hypothesis got rejected. So, it proves Digital marketing in e-recruitment doesn't generate e-candidate pipeline

Hypothesis 3

Here Brand significant value is (0.000). As the significant value is less than .05 So, here Null Hypothesis got rejected and alternative hypothesis got accepted.

So, it proves Digital marketing in e-recruitment develops brand awareness of a company

\section{Discussion}

The findings of this study are consistent with those of (Hosain et al., 2020) and (Khashman \& Khashman, 2016). Based on the findings, it is hoped and anticipated that this preliminary and empirical study on this priority sector will be very useful for managers and other stakeholders in carrying out the necessary e- recruitment practices with the help of digital marketing. Adoption of digital marketing in e-recruitment can be advantageous because it can reduce unnecessary costs, increase efficiency, and reduce the waste of working hours.

Furthermore, such a study may be useful for academics, practitioners, andl analysts who wish to conduct research on e-recruitment applications in these sectors in the future (Muqaddim \& Hosain, 2021). As previously stated, this is one of the first attempts to investigate the impact of digital marketing adoption in e- recruitment on operational efficiency in some industries; the findings can be used as yardsticks for future research investigations . 
The Internet has had a positive impact on how businesses recruit employees. Adoption of digital marketing and e-recruitment systems is new and rapidly increasing, but traditional methods of recruiting, such as through newspapers or employee referral, have not become obsolete (Kashi \& Zheng, 2013).

There is no doubt that the number of internet users in Bangladesh is growing, but penetration remains low; in most cases, they use the Internet for specific purposes. As a result, studying digital marketing in conjunction with e-recruitment is critical in order to maximize its financial and non-financial benefits for both employers and job seekers. According to the findings of this study, the use of digital media for job searching is positively influenced (Hosain et al., 2016).

\section{Recommendation}

Based on the above result from analysis in this study and the fact that adoption of digital marketing is acting as a bridge for e recruitment success and the factors have influence on it. The following recommendations can be made to the HR departments operating in the private sector companies of Bangladesh:

Companies should post job openings on their websites rather than in newspapers or other forms of media. To make the sites more appealing to candidates, adequate job information (such as salary and benefits, job location, job description and specification, and job prospects) should be placed. To make the websites more user-friendly, they should be easy to navigate. Developers of job sites should place a greater emphasis on brand awarenesis and reach.

\section{Limitations}

Although every effort has been made to conduct a comprehensive research study, there are some limitations to the study due to time constraints. The study's sample consists of 138 responses from people living in two major cities in Bangladesh. More respondents from more locations, all job sectors/industries, and more organizations (small to large) operating in Bangladesh can broaden the scope of the research.

\section{Conclusion}

This study is one of the most burning question in Bangladesh. After the thorough analysis and interpretation, it can be said that out of three independent variables minimizing recruitment cost \& time, this variable has great impact on the adoption of digital marketing in e-recruitment in different sectors in Bangladesh. Another variable developing brand awareness also creates impact and contributes to adoption of e-recruitment effectiveness in different sectors in Bangladesh. All of the methods and techniques showed the influence of independent factors possess over the dependent variable. This study surely will contribute to the society and hope that the findings will support in making the decisions in Digital Marketing \& HR sector, only then this effort will be a triumph for us. 


\section{References}

Andrade, C. (2020). The Inconvenient Truth About Convenience and Purposive Samples. Indian Journal of Psychological Medicine, 43(1), 86-88. https://doi.org/10.1177/0253717620977000

Anand J, D. C. (2016). The Impact of E-Recruitment and challenges faced by HR Professionals. International Journal of Applied Research, 410-413.

Backhaus, K., \& Tikoo, S. (2004). Conceptualizing and researching employer branding. Career Development International, $\quad 9(5), \quad 501-517$. https://doi.org/10.1108/13620430410550754

Barber, L. (2006). E-Recruitment Developments. Institute for Employment Studies.

Batinić, I. (2015). The Role and Importance of Internet Marketing Modern Hotel Industry y. (JPMNT) Journal of Process Management - New Technologies, International, 3(3).

Boyd, D.M. \& Elliston, N.B. (2007). Social network sites: definition, history, and scholarship. Journal of Computer-Mediated Communication, 13(1), 210-230. https://doi.org/10.1111/j.1083-6101.2007.00393.x

Check, J. W., \& Schutt, R. K. (2011). Research Methods in Education (First ed.). SAGE Publications, Inc. https://doi.org/10.4135/9781544307725

Christensen, H.K. (2011). Political activities on the internet: slacktivism or political participation by other means?. First Monday, 16(2), 2-7. https://doi.org/10.5210/fm.v16i2.3336

Cooper, D. R., \& Schindler, P. S. (2014). Business Research Methods (12th ed.). McGraw-Hill Education.

Davies, G. (2008). Employer branding and its influence on managers. European Journal of Marketing, 42(5/6), 667-681. https://dx.doi.org/10.1108/03090560810862570

Davis, F. D. (1989). Perceived Usefulness, Perceived Ease of Use, and User Acceptance of Information Technology. MIS Quarterly, 13(3), 319. https://doi.org/10.2307/249008

DeKay, S. (2008). Are Business-Oriented Social Networking Web Sites Useful Resources for Locating Passive Jobseekers? Results of a Recent Study. Business Communication Quarterly, 72(1), 101-105. https://doi.org/10.1177/1080569908330378

Fraenkel, J., Wallen, N., \& Hyun, H. (2011). How to Design and Evaluate Research in Education (8th ed.). McGraw-Hill Education.

Galanaki, E. (2002). The decision to recruit online: a descriptive study. Career Development International, 7, 243-251.

Gelhena, L. G. and Liyanage, D. M. (2014). Effect of E-Recruitment on Behavioral Intention of Candidates: Empirical Evidence from Management Undergraduates in Sri Lanka. 
Reshaping Management and Economic Thinking through Eco-Friendly and Ethical Practices, Proceedings of the 3rd International Conference on Management and Economics.

Gavurova, B., Bacik, R., Fedorko, R., \& Nastisin, L. (2018). The Customer's Brand Experience in the Light of Selected Performance Indicators in the Social Media Environment. Journal of Competitiveness, 10(2), 72-84. https://doi.org/10.7441/joc.2018.02.05

Ghannam, J. (2011), "Social media in the Arab world: leading up to the uprisings of 2011", Centre for International Media Assistance, 3, 1-44.

Herbell, K., \& Zauszniewski, J. A. (2018). Facebook or Twitter?: Effective recruitment strategies for family caregivers. Applied Nursing Research, 41, 1-4. https://doi.org/10.1016/j.apnr.2018.02.004

Hosain, M. S., Arefin, A. H. M. M., \& Hossin, M. A. (2020). E-recruitment: A Social Media Perspective. Asian Journal of Economics, Business and Accounting, 51-62. https://doi.org/10.9734/ajeba/2020/v16i430248

Hosain, M. S., Ullah, K. T., \& Khudri, M. M. (2016). The Impact of E-recruitment on Candidates' Attitudes: A Study on Graduate Job Seekers of Bangladesh. Journal of Human and Social Science Research, 8(1).

Internet | BTRC. (2021). BTRC. http://www.btrc.gov.bd/telco/internet

Jones, N., Borgman, R., \& Ulusoy, E. (2015). Impact of social media on small businesses. Journal of Small Business and Enterprise Development, 22(4), 611-632. https://doi.org/10.1108/jsbed-09-2013-0133

Karim, M. R., Miah, M. S., \& Khatun, A. (2015). E-Recruitment in Practice: A Study on Jobseekers' Perception in Bangladesh. Global Disclosure of Economics and Business, 4(1), 33-42. https://doi.org/10.18034/gdeb.v4i1.150

Kashi, K., \& Zheng, C. (2013). Extending Technology Acceptance Model to the E-recruitment Context in Iran. International Journal of Selection and Assessment, 21(1), 121-129. https://doi.org/10.1111/ijsa.12022

Kaur, G. (2017). The Importance of Digital Marketing in the Tourism Industry. International $\begin{array}{llll}\text { Journal of Research } & \text {-GRANTHAALAYAH, }\end{array}$ https://doi.org/10.29121/granthaalayah.v5.i6.2017.1998

Khashman, I. M. A., \& Khashman, A. M. (2016). The Impact of Human Resource Information System (HRIS) Applications on Organizational Performance (Efficiency and Effectiveness) in Jordanian Private Hospitals. Journal of Management Research, 8(3), 31. https://doi.org/10.5296/jmr.v8i3.9419

Khlebarodava, H., \& Remeikiene, R. (2019). Opportunities of E-recruitment through social media platforms and its development in Lithuania.VADYBA, 34(1), 25-41. 
Kumar, A., \& Priyanka, S. (2014). A study on adoption of E-recruitment using Technology Acceptance Model (TAM) with reference to graduating students in universities in Bahrain. International Journal of Advance Research in Computer Science and Management, 2(9).

Liu, Y., Pencheon, E., Hunter, R. M., Moncrieff, J., \& Freemantle, N. (2018). Recruitment and retention strategies in mental health trials - A systematic review. PLOS ONE, 13(8), e0203127. https://doi.org/10.1371/journal.pone.0203127

Mathis, R. L., Jackson, J. H., Valentine, S. R., \& Meglich, P. (2016). Human Resource Management (15th ed.). Cengage Learning.

McKinsey (2012), "The social economy: unlocking value and productivity", available at: https://www.mckinsey.com/.../media/McKinsey/.../The\%20social\%20economy/MGI_The, (accessed 25 November 2017).

Melanthiou, Y., Pavlou, F. and Constantinou, E. (2015). The use of socilal network sites as ane-recruitment tool. Journal of Transnational Management, 20(1), 31-49. https://doi.org/10.1080/15475778.2015.998141

Mondy, W. R., \& Martocchio, J. (2015). Human Resource Management (14th ed.). Pearson.

Mindia, P. M., \& Hoque, M. K. (2018). Effects of E-recruitment and internet on recruitment process: An Empirical study on Multinational companies of Bangladesh. International Journal of Scientific Research and Management, 6(01). https://doi.org/10.18535/ijsrm/v6i1.em01

Mishra, S., \& Kumar, S. P. (2019). E-recruitment and training comprehensiveness: untapped antecedents of employer branding. Industrial and Commercial Training, 51(2), 125-136. https://doi.org/10.1108/ict-12-2017-0106

Muqaddim, N., \& Hosain, M. S. (2021). E-HRM Practices and Operational Efficiency: Evidence from Bangladeshi Garment Industry. Asian Journal of Economics, Business and Accounting, 81-96. https://doi.org/10.9734/ajeba/2021/v21i430373

Nikolaou, I. (2014). Social Networking Web Sites in Job Search and Employee Recruitment. International Journal of Selection and Assessment, 22(2), 179-189. https://doi.org/10.1111/ijsa. 12067

Ngai, E. L. (2007). Importance of the internet to human resource practitioners in Hong Kong. Personnel Review, 37(1), 66-84. https://doi.org/10.1108/00483480810839978

Ollington, N., Gibb, J., \& Harcourt, M. (2013). Online social networks: an emergent recruiter tool for attracting and screening. Personnel Review, 42(3), 248-265. https://doi.org/10.1108/00483481311320390

Pollitt, D. (2004). Helps Xerox to pick the cream of the crop. Human Resource Management International Digest, 12(5), 33. https://doi.org/10.1108/09670730510586995

Pollitt, D. (2005). Gets the Nike tick for approval. Human Resource Management International Digest, 13(2), 33. 
Rahman, M. S., \& Hosain, M. S. (2021). E-HRM Practices for Organizational Sustainability: Evidence from Selected Textile Firms in Bangladesh. Asian Journal of Economics, Business and Accounting, 1-16. https://doi.org/10.9734/ajeba/2021/v21i130335

Rahman, M., Aydin, E., Haffar, M., \& Nwagbara, U. (2020). The role of social media in e-recruitment process: empirical evidence from developing countries in social network theory. Journal of Enterprise Information Management. https://doi.org/10.1108/jeim-12-2019-0382

Rana, T., \& Singh, N. (2016). Social Media as a Tool for Recruitment-a Critical Study. International Journal of Science Technology and Management, 5(5).

Reis, G. G., \& Braga, M. B. (2016). Employer attractiveness from a generational perspective: Implications for employer branding. Revista de Administração, 51(1), 103-116. https://dx.doi.org/10.5700/rausp1226

Sabrina Jahan, S. (2014). Human Resources Information System (HRIS): A Theoretical Perspective. Journal of Human Resource and Sustainability Studies, 02(02), 33-39. https://doi.org/10.4236/jhrss.2014.22004

Saunders, M. L. P. T. A. N. K. (2019). Research Methods For Business Students. PEARSON.

Scott, J. (2017). Social Network Analysis, 4th ed., Sage. https://doi.org/10.4135/9781529716597

Shiraz, F. (2013). Social media and the social movements in the Middle East and North Africa. Information Technology and People, 26(1), 28-49. https://doi.org/10.1108/09593841311307123

Sultana, N. (2017). Analyzing the Effectiveness of Online Recruitment: A Case Study on Recruiters of Bangladesh. Asian Business Review, 7(2), 79-84. https://doi.org/10.18034/abr.v7i2.14

Sultana, N., \& Sultana, N. (2017). Analyzing the Effectiveness of Online Recruitment: A Case Study on Recruiters of Bangladesh. Asian Business Review, 7(2), 79-84. https://doi.org/10.18034/abr.v7i2.14

Sylva H, Mol ST. (2009) E-recruitment: A study into applicant perceptions of an online application system. International Journal of Selection and Assessment, 17(3), 311-323. https://doi.org/10.1111/j.1468-2389.2009.00473.x

Tong, D.Y.K. and Sivanand, C.N. (2005). E-recruitment service providers review: international and Malaysian. Employee Relations, 27(1), 103-117. https://doi.org/10.1108/01425450510569337

Wasserman, S. and Faust, K. (1994). Social Network Analysis: Methods and Applications, Cambridge University Press, Cambridge. https://doi.org/10.1017/CBO9780511815478

Wołodźko, K., \& Woźniak, J. (2017). The Use by Large Polish Organizations of Information about CSR Activities in e-Recruitment. Economics \& Sociology, 10(2), 47-60. https://doi.org/10.14254/2071-789x.2017/10-2/4 
Wroblowska, Z. (2016). Requirements for Brand Managers and Product Managers Responsible for Competitiveness of Product and Brands. Journal of Competitiveness, 6(3), 5-21. https://doi.org/10.7441/joc.2016.03.01

Yoon Kin Tong, D. (2009). A study of e-recruitment technology adoption in Malaysia. Industrial Management \& Data Systems, 109(2), 281-300. https://doi.org/10.1108/02635570910930145

Zoonen, W. and Rice, R.E. (2017). Paradoxical implications of personal social media use for work. New Technology, Work and Employment, 32(3), 228-246. https://doi.org/10.1111/ntwe.12098 